\title{
Niedźwiedź z bliska jak żywy
}

\section{Elżbieta Kiślak}

TEKSTY DRUGIE 2016, NR 2, S. 402-411

DOI: $10.18318 /$ td.2016.2.22

Została po nim pustka. Praca u niego to byta niesamowita przygoda.

To byto coś więcej niż praca.

To takie dziesięć minut wżyciu,

które się pamięta do końca.

Agnieszka Ptak, pielęgniarka ${ }^{1}$
Elżbieta Kiślak - dr hab., prof. IBL PAN, autorka Walki Jakuba z aniołem. Czesław Miłosz wobec romantyczności oraz wielu studiów o Miłoszu.

A gnieszka Kosińska opublikowała swoją najważniejszą zapewne książkę poświęconą Miłoszowi, a warto przypomnieć, że wśród różnych prac jemu poświęconych ma na koncie również Rozmowy o Miłoszu, złożone z wybranych wywiadów, w których opowiadała szczegółowo i barwnie o swojej przygodzie sekretarki. Nie kryje jednak, że Miłosz w Krakowie ${ }^{2}$ jest wyjątkowy, i trudno z tym się nie zgodzić - choćby dlatego, że osobista relacja z sekretarzowania nobliście została tutaj wpisana w znacznie bardziej

1 A. Ptak Dziesięć minut wżyciu, w: Obecność. Wspomnienia o Czesławie Miłoszu, wyb., red. i oprac. A. Romaniuk, PWN, Warszawa 2013.

2 A. Kosińska Miłosz w Krakowie,Znak, Kraków 2015. (W nawiasie numerystron). 
intymną perspektywę drobiazgów codzienności, trywialnych i może nawet zwyczajnie nudnych, ale dostępnych tylko w hermetycznej przestrzeni życia prywatnego, więc mimo pospolitości jedynych w swoim rodzaju: prowadza przecież do swoistego wtajemniczenia, służą za przepustkę do kręgu publice niedostępnego, pozwalają oglądać pomnikową wielkość w ludzkim wymiarze. Trudno znaleźć analogię dla tego osobliwego tomu, który amorficzną, płynną, żywiołową materią życia potrafi przykuć uwagę czytelnika, ukazując zwyczajną apokalipsę poety (w etymologicznym sensie tego słowa - apokalyptein to ujawniać, odsłaniać), jakkolwiek niektóre wspomnienia ze zbioru Obecność sugerują podobnie bliski stopień konfidencji z Miłoszem. Książka jest hybrydą, o formie swobodnej i pojemnej - jeśli dziennikiem, to ułomnym i przełamującym reguły diarystyki, bo zapiski sprzed lat kilkunastu bywaja wzbogacone eksploracją „przepastnej pamięci” autorki czy opatrzone współczesnym komentarzem i spuentowane wiedzą nabytą później; czasem skrót myślowy więcej w notce ukrywa niż wyjaśnia, co może wskazywać, że autorka nie zawsze liczyła się z ich upublicznieniem i potencjalnym czytelnikiem. Tę fragmentaryczną, hybrydyczną narrację bierze w scalające ramy obszerny, autonomiczny wstęp, który, jak przedtem liczne wywiady, podsumowuje zwięźle doświadczenia nie tylko ośmiu lat pracy z Miłoszem, ale prawie dwudziestu lat namysłu nad nim i obcowania z jego dorobkiem - zarysowuje stały rytm dnia poety i wprowadza w codzienne rytuały z dodatkiem krótkiego przewodnika po twórczości, uwzględniającego jej dynamikę i paradoksy, skądinąd bardzo przydatnego dla laików - czyli szerokiego kręgu czytelników.

Kalendarium wypełniane bywało chimerycznie, w nierównym tempie i nieproporcjonalnie, zwłaszcza na początku - pierwsze cztery lata zajmują zaledwie osiemdziesiąt stron z przeszło siedmiuset, a część tych zapisów odzwierciedla po prostu terminarz: „praca z CM, korespondencja - którą w przeciwieństwie do adresata sekretarka czytała w całości - umowy wydawnicze" plus mnożące się sprawy dodatkowe, ale pierwszorzędne, jak logistyka wyjazdów i występów, kontaktów z mediami, konsultacje z prawnikiem, wizyty w bankach i urzędach, kwerendy w bibliotekach i archiwach, prenumerata prasy na adres amerykański, porządkowanie papierów, a nawet zaprojektowanie firmowej papeterii dla instytucji Miłosz. Już z tej niepełnej, imponującej listy wynika, że praca wymagająca wszechstronności, do której tylko po części przygotowało Kosińską doświadczenie zdobyte na posterunkach w krakowskim SPP i „Dekadzie Literackiej”, wykraczała daleko poza standardowe kwalifikacje sekretarki (języki i tzw. maszynopisanie); Kosińska zaprezentowała dodatkowe walory, uważność, dokładność, pracowitość, 
wytrwałość - powierzone jej sprawy doprowadzała do końca, nie zrażając się przeszkodami - umiejętność przewidywania, pomysłowość, a do tego niezwykłą łatwość nawiązywania kontaktów i, last but not least, poczucie humoru, które starszy syn Miłosza zdefiniował z pełną akceptacją autorki: „Agnieszka odczuwa absurd życia w każdym momencie, i to w dodatku na wesoło" (370). Mimo wszystko w tym pierwszym okresie sekretarzowanie poecie nie wydawało się aż tak bardzo absorbujące, poniekąd dlatego, że Miłoszowie swój czas dzielili jeszcze przez kilka sezonów między Polskę i Kalifornię, a Kraków służył im w czasie letnich miesięcy za bazę wypadową do częstych podróży. Co prawda, w tych pierwszych latach, w mijającej erze faksu i snail mail, pojawiły się zadania wynikające właśnie z nieobecności Miłoszów na Bogusławskiego, doglądanie mieszkania, remontowanego i nękanego regularnymi awariami, i występowanie per procura Miłosza np. przy ciągnących się formalnościach, związanych z kupnem przyległego lokalu lub zamówieniach u krawca. W zapiskach Kosińskiej z tego okresu, skupionych na sekretarskiej krzątaninie, sam noblista pojawia się z rzadka, w kilku prywatnych sytuacjach, także groteskowych, krótkich enuncjacjach czy też wzmiankach o rozmowach, w których odsłonił gusta, słabości czy animozje. Rozliczne obowiązki, nie zawsze nagrodzone wdzięcznością, opromienia może nie „szczera wściekłość", jak w jednym z wierszy z Miłoszowego kanonu, lecz lekkie rozżalenie wobec pracodawców, dystans, ironia i krytyczne spojrzenie. Przepisując nowy wiersz Miłosza, Kosińska przywołuje ciąg niespodziewanych kontekstów, ukazujących poetę z innej, właśnie krytycznej perspektywy - z punktu widzenia jej przyjaciela, Jana Goślickiego. Z racji pracy w SPP obyta z całym środowiskiem literackim i luminarzami literatury, daleka jest od hołdowniczej, „kolanopokłonnej”, postawy wobec noblisty, chociaż będzie konsekwentnie okazywała należny profesorowi szacunek. I w tej książce, i przy wielu innych okazjach podkreśla jednak przekornie, że Miłosz nigdy nie był jej autorem, że sama umieszcza się na linii Gombrowicza (to Kronos utwierdził ją w przekonaniu o wartości swoistej „buchalterii życia”, znaczeniu zwykłych faktów na osi czasu), że bliższy jej byłby Iwaszkiewicz czy Białoszewski. Porównywany z innymi wielkościami jej pracodawca nie zawsze wychodzi zwycięsko - według niej Herberta odznaczało znacznie większe poczucie humoru, a w sporze o ketmana rację miał Herling-Grudziński. Atencja dla twórcy nie może więc zniekształcić jej widzenia, kiedy postrzega Miłosza jako „uparciucha, niepogodzonego ze światem i porządkiem bosko-ludzkim”(97), współcierpiącego jednak ze zwykłymi ludźmi, którzy ślą do niego listy. Żaden autorytet nie hamuje też jej dowcipu, chociaż chyba dopiero mniej więcej po 
trzech sezonach pracy sekretarka zaczyna odnotowywać niektóre docinki, nieco ryzykowne, bo godzące w próżność poety, którą szczęśliwie tonuje zwykle jego autoironia. Kolekcjonuje groteskowe scenki, w których kreaturalność i trywialność zderza się niejako z mitem, kiedy na np. Miłosz przybierając pozę proroka, czyta wraz z nią przepowiednie Wernyhory, z rytmem łudząco przypominającym Przygody koziołka Matołka.

Obowiązki się spiętrzają, kiedy Miłoszowie decydują się osiąść w Krakowie jesienią 2000 roku, i kołowrót spraw do załatwienia zaczyna krążyć w coraz szybszym tempie, księga gości i petentów pęcznieje, Miłosz jest „spożywany" na różne sposoby, zarzucany prośbami i zapraszany do rozmaitych inicjatyw ${ }^{3}$, których kulisy można tutaj poznać. W pracy sekretarki brak już długiej przerwy pod nieobecność gospodarzy, trwającej na początku większą część roku, udziałem Kosińskiej staje się czuwanie nad szeregiem spraw administracyjno-urzędowych i przekonuje się ona wielokrotnie, o czym zresztą zdążyła dowiedzieć się wcześniej, jak sława noblisty utrudnia rutynowe procedury, z drugiej zaś strony - nie chroni przed życiowymi problemami, włamaniem do piwnicy czy wreszcie upokarzającym traktowaniem przez lekarza w szpitalu. Miłosz wymaga teraz na ogół codziennej, ośmiogodzinnej pracy w swoistym biurze, której nie przerywa nawet łańcuch wizyt.

Kolejną i najważniejszą cezurę stanowi odejście Carol Thigpen zaledwie w dwa lata później, zmiana dostrzegalna dla wielu: „W domu było zupełnie inaczej, pusto, zimno, głucho. [...] Potem był już schemat, schemat dnia, życia. Wcześniej był stały rytm i miejsce na spontaniczność, i te dwie sfery mieszały się"4. Od kiedy wraz z tym niespodziewanym paradoksem nagłej, nieuleczalnej choroby prawie o dwa pokolenia młodszej żony śmierć wkracza na Bogusławskiego, a Miłosz, chociaż w ciągu roku doszedł do formy, stopniowo zaczyna osuwać się w definitywną rezygnację, Kosińska zbiera najdrobniejsze ułamki z obcowania z poetą, aby uchronić życie przed śmiercią5. Dwa kolejne, ostatnie lata to także przejęcie części domowych obowiązków po zmarłej, rola „majordomy”.

3 Pojęcie o tym, jak różnych, daje list z Muzeum Guzików w Łowiczu z prośbą o guzik. Autorka nie wspomina, czy to życzenie zostało spełnione - jak wiele innych różnego kalibru - natomiast na stronie internetowej Muzeum posiadaniem guzika Miłosza się nie chwali.

4 A. Ptak Dziesięć minut wżyciu, s. 592.

5 Nb. zastanawiające są słowa poety z 29 stycznia 2004 roku: "Już nie napiszę historii powiatu kowieńskiego" (509). Czy nie byłby to lapsus Miłosza (lub pomyłka w zapisie), honorowego obywatela Kiejdan, podkreślającego często swoje pochodzenie z powiatu kiejdańskiego, a także odrębność swojego powiatu? 
Powstała z codziennych zapisków książka to świadectwo unikatowe; co więcej, nie ma chyba podobnego w polskiej biografistyce - narracji dającej tak realistyczny portret pisarza w rodzajowych scenach, starca borykającego się z dotkliwą fizjologią, chociaż można też sięgnąć do kilku wspomnień ze zbioru Obecność, nieomijających również i tego tematu (wypowiedzi pielęgniarek, obecnych na Bogusławskiego nieprzerwanie od jesieni 2000 roku). Mozaikowy, ułożony z codziennych drobiazgów krakowski wizerunek Miłosza może frapować swoim realizmem, nawet jeśli przeważałby tu mały, skupiony na rzeczach, kronikarski realizm. Rysuje się tu obraz mało komu znany, bo też Miłosz był nader, wręcz staroświecko powściągliwy w kwestii życia prywatnego. Kosińska eksponuje szczegóły, ale zdobywa się też na rozmach radykalnych wniosków; ujmuje proteuszowość poety w obrazowe metafory, nie tylko podkreślając sprzeczności, ale też jeszcze wyraziściej jego rysy utajone lub stereotypizowane - codzienne doświadczenie przydaje im wiarygodności. Miłosz firmujący swoiste przedsiębiorstwo, które jego sekretarka porównuje do kancelarii prezydenta, uwielbiający odgrywać rolę pisarza (wieczory autorskie, autografy), to w gruncie rzeczy introwertyk (jeśli nie "printrovert", według angielskiego terminu introwertyk przedkładający książki nad towarzystwo ludzkich istot), niecierpiący funkcji reprezentacyjnych, w całości skupiony na swojej pracy. Kosińska podziwia jego pracowitość, lotność umysłu, przenikliwość w ocenie wypadków, prorocze prognozy, ale irytują ją też jego reakcje, które opisując zresztą, pozostawia często bez komentarza. Zdarzają się tu passusy odbrązowienia radykalnego, nieliczącego się z ograniczeniami wieku: „Czy może być dla mnie wyzwaniem intelektualnym człowiek, którego nie interesuje ani muzyka, ani malarstwo, ani film, ani taniec, ani sport. Drugi człowiek w gruncie rzeczy też nie” (606). Natomiast ją ciekawi właśnie znacznie bardziej człowiek niż twórczość: „Mnie interesuje CM jako pewien okaz ludzki, dziwowisko, jak się mawiało na wsi. Jak taki człowiek robi takie wiersze? No i oczywiście bardzo go lubię. Przede wszystkim dlatego, że jest wymagający, a to świetny dla mnie napęd. No i jeszcze dlatego, że się stara. To człowiek, który nie odpuszcza" (606). Nie znaczy to, że w książce nie znalazły się warte namysłu i dyskusji interpretacje twórczości. Kosińska śmiało wygłasza sądy podważające znany wizerunek: widzi w Miłoszu nie współczesnego klasyka i mistrza, spełnioną wielkość, lecz niespełnione możliwości, a nawet - zagubienie.

Dla miłoszologów - i z pewnością nie tylko - ta książka, dając tak wyrazisty obraz poety, stanowi swoiste wyzwanie, co więcej - przykład odwagi odczytywania Miłosza na przekór utartym sądom, wbrew kierunkom, które 
sam wyznaczył, choć jeden z zasadniczych motywów jego dzieła - zainteresowania religijne, metafizyczne, mistyczne - został tu nie tylko zweryfikowany, ale i uwydatniony, wręcz wysunięty na plan pierwszy. Jest też kopalnią odkrywkową, z bogatymi złożami - dwoma tysiącami nazwisk, dwoma tysiącami tytułów - jak szacuje autorka w jednym z wywiadów - z wieloma zastanawiającymi szczegółami, mniej lub bardziej przydatnymi. Wiadomo stąd, że poeta sympatią darzył żaby, lekceważył brzozy, cenił dęby, a nie lubił słów „źródło” i „skarbnica”. Więcej dowiedzieć się tu można o jego stosunku do polskiej rzeczywistości z przelotnych uwag, które czasem odsłaniaja oblicze politycznie niepoprawnego moralisty. Rzucić dodatkowe światło na miłoszologiczne tematy mogą znaczące, choć mimochodem wygłaszane komentarze poety, wśród nich zaskakujące, krytyczne autokomentarze, obok dowodów ogromnej idiosynkrazji na krytykę. Osobliwe są jego podsumowania prac na swój temat, z polemikami włącznie, które pilnie śledził. Kosińska podaje powiedzonka, domowe idiomy, cięte riposty, rzadkie anegdoty, reakcje na powtarzane plotki ze środowiska literatów (jakimś, choć nie najmocniejszym usprawiedliwieniem tego plotkarstwa jest to, że życie literackie, dla postronnych uładzone, z tej perspektywy nabiera dynamiki), oceny książek i kolegów po piórze dalekie od oficjalnych hierarchii, zwięzłe portrety ludzi, tworzące skomplikowaną siatkę animozji i przyjaźni. Przewijają się tu fragmenty niepublikowanej korespondencji i wzmianki o dyktowanych listach, nie wspominając o wymianach zdań, cytowanych za przykładem Eckermanna. Są i rzeczy podstawowe dla wiedzy filologa: Kosińska relacjonuje proces powstawania utworów, uświadamia, jaką wagę Miłosz przywiązywał do najdrobniejszego szczegółu, do korekty, dając przedsmak obcowania z pełnymi poprawek palimpsestami rękopisów; ważne są wzmianki nie tylko o tekstach pisanych, ale też o tych nieopublikowanych (i przyczynach wstrzymania druku), oraz informacje o czasem trudnym do wyśledzenia udziale Miłosza w publikacjach „niszowych” - jak np. wstęp do prac literackich osób chorych psychicznie, wydanych w Lublinie, czy tekst do księgi pamiątkowej ku czci działającej w Berkeley litewskiej archeolożki Mariji Gimbutas. W pracy nad ostatnią książką, Spiżarnią literacka, prawie w całości dyktowaną, Kosińska skrupulatnie odnotowuje warianty. Bardzo intrygująca okazuje się lista lektur, niepełna, rzecz jasna, bo sekretarka nie była przecież na Bogusławskiego jedyną lektorką, a poeta w okresie, kiedy korzystał jeszcze z tzw. maszyny do czytania, mógł nikomu nie opowiadać się z czytelniczych wyborów. Pojawiają się, czasem powtarzane w Spizarni, reminiscencje lub informacje o dawniejszych lekturach, jak pismo białych Rosjan, wydawane w Berlinie z debitem 
na okupowaną Polskę. Wbrew pozorom, czy raczej kilku autokomentarzom, poeta okazuje się tu koneserem powieści. Zadziwia znakomita, nadzwyczajna orientacja Miłosza w literaturze najnowszej, a szczególnie w obfitej produkcji poetyckiej, jego wytrwałość w śledzeniu polskiej poezji, jego radość z odkrywanych talentów, uwaga, a też i opieka, jaką darzył debiutantów. Odnotowane są oglądane filmy, zwłaszcza ostatnie wyjścia do kina; istnieją dwie sprzeczne relacje na temat tego, jak oceniał adaptację Solaris Soderbergha (Elżbieta Ptak, lekarka, stwierdziła, że przychylnie), ale na pewno przyjemność sprawił mu Pinokio - w arlekinadzie Benigniego można doszukać się odbicia niejednego Miłoszowskiego tematu, a wróżka o niebieskich włosach mówi tutaj już w pierwszej scenie: „Jedyne, co mi się nie podoba w śmierci - to, że trwa zdecydowanie za długo".

Jedna trzecia książki to zapis ostatniego roku, kiedy sekretarka staje się świadkiem słabnięcia poety, starości zmierzającej konsekwentnie do oderwania się od spraw tego świata. Książka Kosińskiej jest właściwie długim pożegnaniem z gasnącym starcem, relacją z traumatycznego przeżycia oczekiwania na nieuchronną katastrofę, wpędzającym w depresję zmaganiem się z cudzą depresją. To dziennik o końcu świata,jak Piosenka... Miłosza dokonującym się w codzienności, wśród zwykłych rzeczy, rutynowych gestów. Przez swoje przymusowe, niechciane doświadczanie starości Kosińska inaczej patrzy na Miłosza: dostrzega w jego pisaniu kruchość i niepewność swojego miejsca i sposobu istnienia.

Spełnienie katastrofy nie przerywa pracy sekretarki, wzbogaca ją o memorialne rytuały. Końcowe sto stron - to okres po śmierci Miłosza, relacja z awantury funeralnej i obcowanie ze spuścizną, inwentaryzowanie rzeczy pozostałych w szufladach i szafach; dokładny spis tych śladów życia jest najzwyczajniej fascynujący. Śmierć właściwie wzmacnia więź Kosińskiej z Miłoszem, zwłaszcza że dopiero wtedy odkrywa w jego komputerze swoje imię w intymnych wyznaniach. Być może rację ma Barbara Gruszka-Zych, która dostrzega upodobnienie się sekretarki do poety; odwiedzając w rok po jego śmierci mieszkanie na Bogusławskiego ogląda w pokoju, gdzie przyjmował przybyszów, dominujące nad przestrzenią popiersie Carol: „Ale jeszcze bardziej obecny jest tu Miłosz. W zdecydowanych sądach Agnieszki, w jej sposobie mówienia, jakiejś mądrości"6. I dodaje, będąc świadkiem jednego z wywiadów o pracy z Miłoszem: „Agnieszka mówi szybko, ma to przemyślane.

6 B. Gruszka-Zych Mój Poeta. Notatki z osobistych spotkań z Czesławem Miłoszem, Videograf II, Katowice 2007, s. 129. 
Mogłaby to wszystko sama świetnie opisać. A może tylko powtarza treść notatek, bo przecież pewnie codziennie zapisywała, co jej mówił? Była przy Nim jedyna, wybrana spośród wielu. Bardzo wymagająca od siebie, dyskretna, nadająca na Jego «fali». Te zapiski - to pewnie była jej powinność, ale również i jedyna możliwość ocalenia intymnej, wspólnej części życia"7.

W kilku wywiadach po ukazaniu się Miłosza w Krakowie autorka ze swadą rozprasza wątpliwości, również te, które nasuwa pytanie zasadnicze: „Co on by powiedział na pani książkę?"8. Kosińska stwierdza, że pisała, patrząc mu prosto w oczy, i przytacza jako argument przychylne oceny Andrzeja Wata, Zofii Ratajczakowej, Katarzyny Herbertowej i Rity Gombrowicz. Raczej jednak nie kierowała się ideą Brodskiego, „sprawić przyjemność cieniowi”, i można zaryzykować hipotezę, że Miłosz nie zawsze zaakceptowałby jej szczerość, jak to się już zdarzyło przy - zapewne trafnej - krytyce jednego z jego przygotowywanych wystąpień. Niektóre zapiski mogłyby wpędzić go w zgrozę ujawnionej prawdy. Wszakże relacja Kosińskiej, nawet jeśli w swojej rzeczowości czasem boleśnie okrutna, ma walor jedynego w swoim rodzaju świadectwa, a Miłosz bywał, mimo miłość własną, wobec siebie bezlitośnie szczery; przynajmniej w swojej poezji, bo Kosińska twierdzi, że - w przeciwieństwie do Zygmunta Mycielskiego - nie umiał „się zdobyć na taką prostolinijną, ale nie naiwną szczerość wobec siebie" (663); prawdopodobnie nie wierzył w możliwość osiągnięcia takiej szczerości w świecie skazanym na pojedynki min, pozy i przebieranki. Odsłaniać się nie lubił wcale, bo nade wszystko cenił sobie rolę poety i nie pragnął ujawniać obrazu nieprzystającego do wyobrażeń czytelników. Ktoś tak jak on wybredny, zwolennik „stopni prawd" i hierarchii, narzucający sobie żelazną dyscyplinę i powściągliwość z innej epoki, źle mógłby znieść tak egalitarystyczne wtajemniczanie we własną intymność. Osobna kwestia, czy zaakceptowałby upublicznianie - m.in. tajemnicami Poliszynela - udręk swego młodszego syna, nawet jeśli, jak tłumaczy Kosińska w innym z wywiadów, czerpał od niego inspirację (np. wykorzystał wzmiankę o jego lekturach w jednym z esejów, jak wynika z jej notatek); czy przyznałby się publicznie do ojcowskiej rozpaczy. Zapiski nie ukazują oczywiście Petera w złym świetle (choć zarazem nie pomijają szczegółów jego stanu), ale wiadomo, z jak wyjątkową konsekwencją Miłosz ochraniał prywatność chorego; zastrzegł korespondencję z księdzem Sadzikiem ze względu

7 Tamże, s. 132-133.

8 Umierałam z Miłoszem. ZAgnieszką Kosińską rozmawia Donata Subbotko, „Książki” 2015 nr 4 (19), S. 53 . 
właśnie na temat Piotra. (Co prawda, ten wątek pojawia się przedtem w biografii Andrzeja Franaszka, który przez pomyłkę bibliotekarzy zyskał dostęp do tych listów.) Kosińska porządkowała na Bogusławskiego korespondencję i przy tej okazji czytała listy syna do ojca, potem zaś służyła za pośredniczkę dla tracącego wzrok poety w wymienianiu e-maili. Jak nikt inny z osób postronnych przeniknęła do wnętrza rodziny Miłoszów. Nie pisze zresztą o ich problemach otwarcie, wyjąwszy kilka aluzji, ale z konieczności przebywała w tym kręgu. To dodatkowa przyczyna tego, że sekretarzowanie wymagającemu i kapryśnemu twórcy wiązało się z wielkimi napięciami - Kosińska w Rozmowach o Miłoszu porównuje tę pracę z przebywaniem na łodzi podwodnej, poddanej ogromnym ciśnieniom. Dla porównania warto przytoczyć świadectwo jednej z pielęgniarek, innej - według dedykacji Miłosza „wspaniałej” i „zabawnej” - Agnieszki: „W ich domu był taki spokój, że nawet po nie wiem jak ciężkim dniu wystarczyło spędzić tam kilka godzin, również przecież pracując, żeby się wyciszyć" ${ }^{\prime \prime}$. Nic dziwnego, że ostateczne wynurzenie - za jakie można uznać Miłosza w Krakowie - też nie jest pozbawione dramatyzmu. Zapiski, w których doszły do głosu emocje, tłumaczy po części sentencja Benjamina Disraeliego: „Nigdy nie przepraszaj za okazywanie uczuć. Kiedy to robisz, przepraszasz za prawdę”. Miejsce pracy, w XX wieku nabierające wyraźnie dla pracowników charakteru publicznego, może się tutaj nałożyć niezbyt fortunnie na cudzą prywatność. Kosińska rozpoznaje niebezpieczeństwo takiego układu: „Nigdy, przenigdy nie chciałabym mieć pani sprzątającej, gosposi, pomocy domowej. Żyć na oczach innych, wszystko docieczone, wszystko pokojarzone. Jak na Wyspach Trobriandzkich" (352). Od początku usilnie stara się oddzielić pracę od swego życia prywatnego, wygospodarować, z coraz większym trudem, świętą przestrzeń od sekretarzowania Miłoszowi niezależną. Zarazem książka, wedle samej autorki, ma służyć jako katharsis, jako wyzwolenie z tego związku, życia cudzym życiem, podsumowanie i zamknięcie doświadczeń z Miłoszem, początek nowego etapu i pisania na tematy od Miłosza odległe. Jednak prawem paradoksu Miłosz w Krakowie utrwala tę zadzierzgniętą, umacniającą się w ostatnich latach bliskość: „Choć nie był moim bohaterem, ani literackim, ani historycznym, ani życiowym, chyba stworzyliśmy zgrany team, skoro tyle lat. Wykonywałam pracę u jego łoża, domowego, szpitalnego, śmiertelnego. Mieliśmy porozumienie" (66o). W istocie - książka umieszcza obydwoje w pułapce zażyłości.

9 A. Ptak Dziesięć minut wżyciu. 
Wszakże, mimo obecności spostrzegawczej obserwatorki, wydaje się, że poeta zdołał ochronić swoją tajemnicę, zatrzeć ślady, pomnożyć niejednoznaczne odpowiedzi - i jego secretum secretorum pozostało poza zasięgiem sekretarki.

\section{Abstract}

\section{Elżbieta Kiślak}

THE INSTITUTE OF LITERARY RESEARCH OF THE POLISH ACADEMY OF SCIENCES (WARSAW)

The Bear at Close Quarters Like in Real Life

Review of Agnieszka Kosińska, Miłosz w Krakowie [Miłosz in Cracow] (Cracow: Znak, 2015)

\section{Keywords}

Czesław Miłosz, biography, diary 